\title{
Importance of grasshopper defoliation period on southwestern blue grama-dominated rangeland
}

\author{
DAVID C. THOMPSON AND KEVIN T. GARDNER
}

Authors are associate professor and graduate research assistant, Dept. of Entomology, Plant Pathology, and Weed Science, New Mexico State University, Las Cruces, N.M. 88003-0003.

\begin{abstract}
Most economic assessments of grasshopper damage are based on how much plant tissue insects consume or destroy without considering factors that influence the ability of individual plants and communities to respond to damage. Properly grazed perennial warm-season grasses, such as blue grama [Bouteloua gracilis (H.B.K.) Lag. ex Griffiths], can withstand considerable defoliation. We investigated the effects of heavy defoliation on blue grama rangeland by caging bigheaded grasshoppers [Aulocara elliotti (Thomas)] during early, mid, and late growing seasons for 2 years in southwestern New Mexico. Peak standing crop (PSC) of blue grama defoliated in the early-season was the same as that in cages protected from defoliation both years. However, peak standing crop of blue grama was reduced in cages defoliated during the mid and late growing seasons in both years. The importance of midseason feeding was compounded by significant changes in relative proportions of various herbage categories in the standing crop. Forbs and sedges made up a larger percentage of the total forage production at PSC after mid-season defoliation during both years. On rangelands where blue grama is dominant, even very high densities of early-season grasshoppers may not influence herbage production. Substantial declines in grasshopper densities observed before summer rains during both years should influence management decisions. Unless early-season forb production is an important part of a ranch management plan, the damage potential of early- and mid-season grasshopper species may be lower on southwestern rangelands where mid- to late-summer precipitation patterns occur than reported in the literature for other areas of the western United States due to later maturation of warm-season grasses. In most years, depending upon precipitation patterns, there may be adequate growth following heavy early-season herbivory to feed both livestock and grasshoppers.
\end{abstract}

Key Words: consumption, insect herbivory, Aulocara elliott, Orthoptera, shortgrass, regrowth

The damage potential of grasshopper populations that compete with livestock for forage in the western U.S. is well known

\footnotetext{
The authors wish to thank the USFS, Silver City Ranger District, Silver City, N.M. for their cooperation and access to field plots and Drs. Reldon Beck and Rex Pieper (New Mexico State University, Dept. of Animal and Range Sciences) for helpful suggestions on earlier drafts of this manuscript. This research was supported in part by a USDA Western Regional IPM grant and the Agricultural Experiment Station, New Mexico State University, Las Cruces, N.M.

Manuscript accepted 1 Jan. 1996.
}

(Anderson 1961, Hewitt et al. 1976, Hewitt 1977, 1978, Hardman and Smoliak 1982, Quinn et al. 1993). The bigheaded grasshopper [Aulocara elliotti (Thomas)] is often the dominant grasshopper species in outbreaks on rangeland (Pfadt 1989) and is an economically important rangeland pest in shortgrass regions of the southwestern U.S. (Ball et al. 1942, Capinera and Sechrist 1982, Pfadt 1982, Thompson et al. 1995). Blue grama [Bouteloua gracilis (H.B.K.) Lag. ex Griffiths], dominant in these shortgrass regions, is a key forage species on many southwestern rangelands (Holechek et al. 1989). In some areas, the bigheaded grasshopper selects blue grama in a higher proportion than its occurrence in the vegetative cover (Pfadt et al. 1988), while in other areas blue grama selection is proportional to its relative availability (Mitchell 1975, Thompson et al. 1995). The loss of livestock forage to insect herbivory is an important consideration in making range management decisions concerning stocking rates and grasshopper control.

Major factors influencing the economics of grasshopper control programs include treatment costs, the value of forage, treatment life, and the timing and efficacy of the treatment (Torell et al. 1987). Published threshold models (Torell et al. 1987, Berry et al. 1991) are based predominately on data derived from northern rangelands of the western U.S. where $C_{3}$ grasses are most common. The economics, however, of controlling grasshoppers on southwestern rangelands where warm-season $\left(C_{4}\right)$ grasses predominate could be much different depending on differences in species longevity, survival, rates of forage destruction, moisture patterns, and the season of herbivory.

Most economic assessments of damage by grasshoppers are based on how much plant tissue is destroyed by insects and ignore factors that influence the ability of individual plants and communities to respond to damage (Quinn et al. 1993). Properly grazed perennial warm-season grasses such as blue grama can withstand considerable defoliation. Detling et al. (1979) state that net photosynthesis and regrowth of blue grama increased following simulated grazing, and Dyer and Bokhari (1976) found that regrowth of blue grama after grasshopper grazing is much higher than after clipping. Given the late summer rainfalls common on southwestern rangelands, blue grama may not be damaged by intensive early-season defoliation by grasshoppers. The objective of this study was to determine the effects of heavy herbivory by the bigheaded grasshopper during early, mid, and late growing seasons on southwestern rangelands dominated by blue grama. 


\section{Materials and Methods}

This experiment was conducted at Fort Bayard, New Mexico (T17S R13W NW 1/4 Sec. 24) during 1989 and 1990. The site is at an elevation of $1,905 \mathrm{~m}$. Long-term average annual precipitation (1897-1983) is $370 \mathrm{~mm}$, primarily received as rain during July and August (Fig. 1). Precipitation and temperatures during this experiment were very close to the long-term averages. The plant community is shortgrass prairie in association with pinonjuniper (Pinus spp. and Juniperus spp.). Blue grama is the dominant grass. Other grasses include black grama [Bouteloua eriopoda (Torr.)], vine mesquite [Panicum obtusum (H.B.K.)], threeawns [Aristida spp.], and other subdominant $\mathrm{C}_{4}$ grasses. Dominant forbs and sedges varied between years; however, prairie mimosa [Desmanthus cooleyi (Eaton) Trel.], dayflower [Commelina diathifolia (Delile.)], broom snakeweed [Gutierrezia sarothrae (Pursh) Britt. and Rusby], and yellow nutsedge [Cyperus esculentus $(\mathrm{L}$.$) ] were most common. The soils are$ Sampson and Dagflat series: fine-loamy, mixed, mesic Pachic Argiustolls and Aridic Argiustolls.

A $36 \mathrm{~m}$ by $36 \mathrm{~m}$ site was fenced to exclude livestock and wildlife. In each year, ninety $0.25 \mathrm{~m}^{-2}$ subsites were selected and
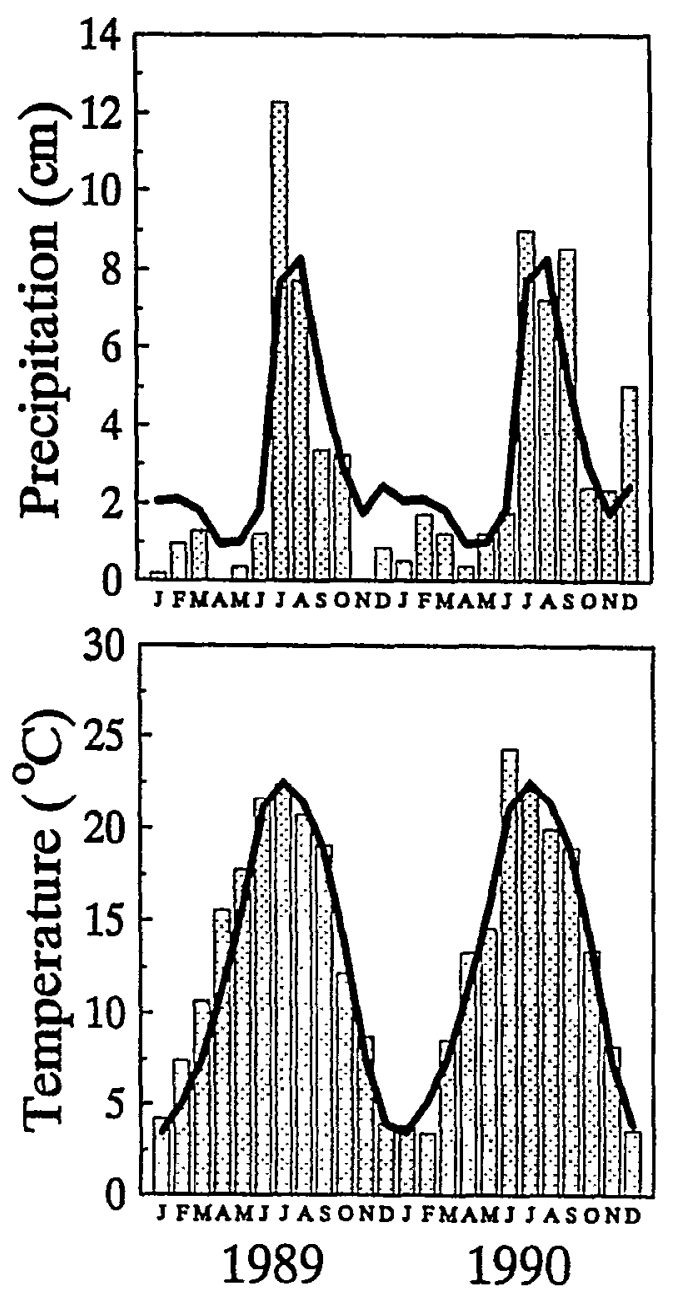

Fig. 1. Monthly temperature and precipitation during 1989 and 1990 at Fort Bayard, N.M. The line represents the long-term 86-year average. species specific foliar cover was estimated using a point frame (50 points per subsite; Bonham 1989). Subsites were ranked based on the percentage cover of live and standing dead blue grama. The 12 subsites with the highest cover and the 12 subsites with the lowest cover were discarded. Cages $(50 \mathrm{~cm}$ by $50 \mathrm{~cm}$ base by $75 \mathrm{~cm}$ tall) constructed of 8 -mesh $(0.3175 \mathrm{~cm}$ by 0.3175 $\mathrm{cm}$ mesh) galvanized hardware cloth were placed over the remaining 66 subsites, and were anchored to the ground using sixteen $60 \mathrm{D}$ common nails fitted with fender washers. Nails were driven through a $5 \mathrm{~cm}$ piece of the hardware cloth folded from the bottom of each side, then soil was banked against the cage to a depth of about $3 \mathrm{~cm}$ to prevent grasshoppers from escaping.

Cages were split randomly into 36 defoliated and 30 nondefoliated plots. The 36 defoliated cages were further divided into 3 groups of 12. Each of the 3 groups was then randomly assigned a defoliation period: 1) Early: 26 June to 5 July 1989 and 12 June to 29 June $1990 ; 2$ ) Mid, 18 July to 31 July 1989 and 18 July to 8 August 1990; and 3) Late, 14 August to 31 August 1989 and 8 August to 30 August 1990. The 30 nondefoliated cages served as controls with no grasshopper feeding.

Twenty adult bigheaded grasshoppers $\left(=80 \mathrm{~m}^{-2}\right)$ were placed into 12 cages at the beginning of each defoliation period. This grasshopper density simulates outbreak populations recorded by Pfadt (1982) on blue grama rangeland in southern Arizona. To quantify feeding pressure, grasshopper density within each cage was counted 3-4 times during the defoliation period. At the end of each defoliation period, all grasshopppers remaining in the 12 cages were removed. Vegetation in 6 of the treatment cages and 6 of the controls was clipped to ground level, separated by species, oven-dried at $60^{\circ} \mathrm{C}$ for 96 hours and weighed. The vegetation in the remaining cages was harvested at peak standing crop (PSC) in early November.

Grasshopper feeding days (GFD) were calculated by plotting grasshopper density levels over time within each cage and integrating under the resulting survival curve (Onsager 1984). Forage destruction rates (consumption and wastage) were estimated using simple linear regression (PROC REG [SAS Institute 1990]). Equations were estimated to predict how much blue grama, forbs and sedges, other grasses, and total herbage (all grasses, forbs, and sedges) remained at the end of each defoliation period and at PSC as a function of feeding pressure (GFD). The slope of each linear regression is an estimate of the biomass removed by one grasshopper feeding for 1 day. The effect of defoliation period and year of treatment on the dry weights and relative composition of blue grama, forbs and sedges, and other grasses were analyzed using the SAS General Linear Models Procedure (SAS Institute 1990). Mean separations were conducted using Least Significant Difference (L.S.D., $P<0.05$ ).

Population dynamics and densities of the major grasshopper species near the study site were estimated using night cages, the most accurate method of establishing species-specific grasshopper population dynamics (Thompson 1988). Twenty $1.0-\mathrm{m}^{2}$ cages were constructed using $2.54 \mathrm{~cm}$ black plastic pipe and nylon window screen. The pipe was used as a base and structure for the walls of the dome-shaped cages. Screen was attached to the circular base, stretched up the sides, and tied at the top to allow access into the cages. On each sampling date, the 20 cages were placed in the field during the coldest time of the day (0400-0600 hours), so that by sunrise all were secured. Cages were staked down and the sides banked with soil to prevent escape of any trapped 


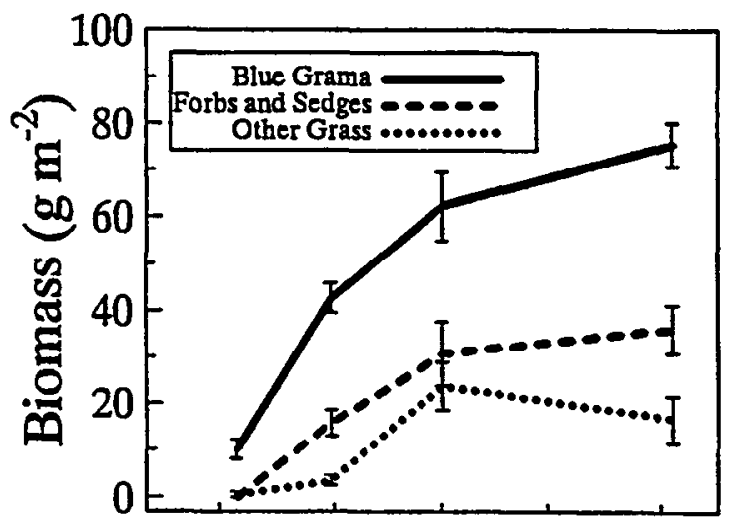

Jul 1 Aug 1 Sep 1 Oct 1 Nov 1 1989

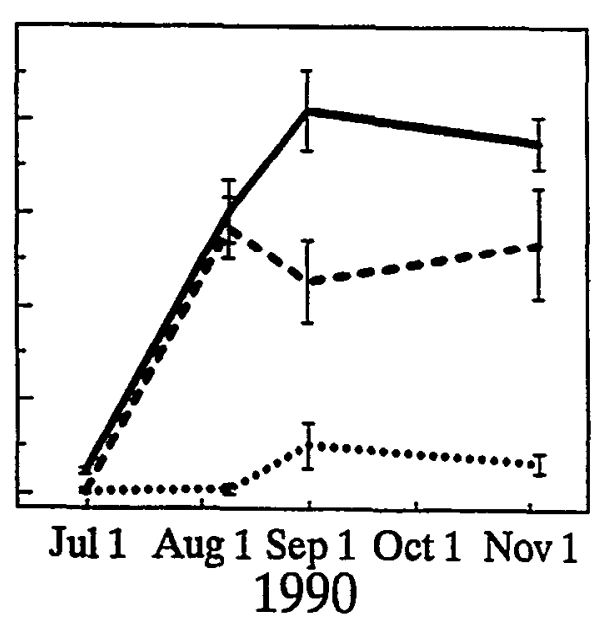

Fig. 2. Aboveground biomass of blue grama, forbs and sedges, and other grasses from control cages protected from herbivory. Each value is the average of six $0.25 \mathrm{~m}^{2}$ cages. Vertical lines denote $\mathrm{SEM}$.

grasshoppers. Once temperatures exceeded $20^{\circ} \mathrm{C}$, the area under each cage was vacuumed using a venturi modified leaf blower similar to that described by Summers et al. (1984). Samples were taken weekly from April through September both years. Grasshoppers from all samples were sorted by species and instar, and mean instar specific density plotted for both years.

\section{Results and Discussion}

The aboveground biomass $\left(\mathrm{g} \mathrm{m}^{-2}\right.$ ) of blue grama, forbs and sedges, and other grasses from control cages protected from herbivory is shown in Fig. 2. In most years, there is very little new growth of warm-season grasses on southwestern rangelands until the beginning of the summer rains in early July (White et al. 1991, Pieper and Herbel 1982). Blue grama biomass and forb and sedge biomass were higher in 1990 than in 1989 at the end of the

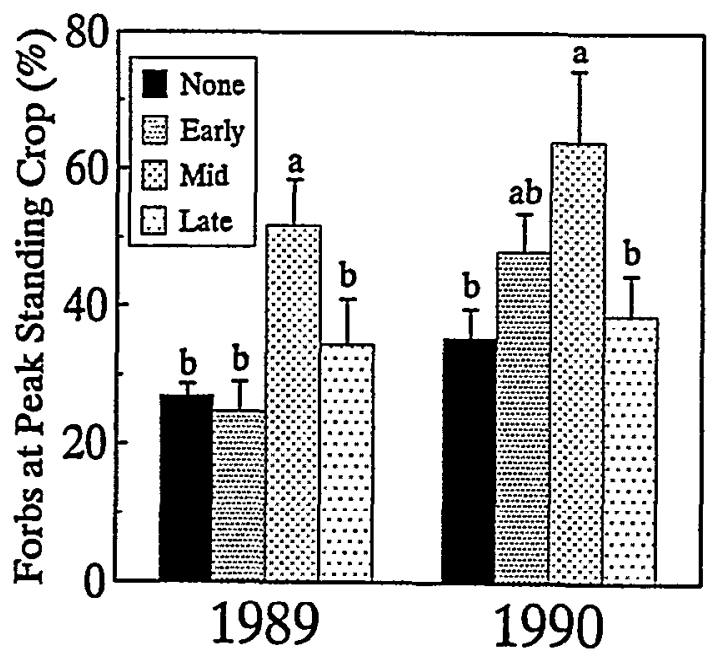

Fig. 3. Percent of total peak standing crop biomass consisting of forbs and sedges, in cages protected from grasshopper defoliation (None) and in cages subjected to early-, mid-, and late-season grasshopper defoliation. Vertical lines denote SEM. Bars within years with the same letter are not different (L.S.D.; $P<0.05$ ). second defoliation period (Blue grama: $P=0.0002$; Forbs and sedges: $P=0.036$ ), while all other biomass estimates were not different between years ( $P>0.05$ ). The increased production in 1990 is probably because precipitation in the first 6 months of 1990 was higher and more evenly dispersed (Fig. 1), and samples were taken 8 days later in 1990. Total herbage production increased rapidly in July: total biomass exceeded $50 \%$ of the peak standing crop biomass by 1 August of both years.

Peak standing crop (PSC) of blue grama from cages in the early defoliation treatment was the same as that in cages protected from defoliation in both years (Table 1), while PSC of blue grama was reduced in cages defoliated during the mid and late periods in both years (Table 1). There were no differences (P> 0.05 ) between PSC of forbs and sedges or other grasses due to defoliation period except in 1989 forb and sedge biomass was higher after mid-season defoliation than after early-season defoliation; however, there was no difference between any of the defoliation periods and the control. Total production was not different between any of the defoliation treatments in 1989. The increases in forb and sedge biomass after mid-season defoliation and relative biomass of other grasses after late-season defoliation compensated for the significant reduction in blue grama grass in 1989.

Table 1. Peak standing crop biomass $\left(\mathrm{g} \mathrm{m}^{-2} \pm \mathrm{SEM}\right.$ ) estimated in early November after heavy grasshopper defoliation occurring early-, mid-, or late-season. Fort Bayard, N.M. 1989 and 1990.

\begin{tabular}{lrlrrr}
\hline \hline $\begin{array}{l}\text { Defoliation } \\
\text { Period }^{1}\end{array}$ & $\mathrm{~N}$ & Blue Grama & Sedges & Other Grass & Total \\
\hline 1989 & & ----- & $----\left(\mathrm{g} \mathrm{m}^{-2}\right)---$ & ------ \\
None & 12 & $76 \pm 5 \mathrm{a}^{2}$ & $36 \pm 5 \mathrm{ab}$ & $17 \pm 5 \mathrm{a}$ & $128 \pm 12 \mathrm{a}$ \\
Early & 6 & $71 \pm 7 \mathrm{a}$ & $28 \pm 9 \mathrm{~b}$ & $9 \pm 4 \mathrm{a}$ & $108 \pm 14 \mathrm{a}$ \\
Mid & 6 & $40 \pm 5 \mathrm{~b}$ & $51 \pm 6 \mathrm{a}$ & $10 \pm 6 \mathrm{a}$ & $100 \pm 8 \mathrm{a}$ \\
Late & 6 & $45 \pm 4 \mathrm{~b}$ & $33 \pm 6 \mathrm{ab}$ & $28 \pm 15 \mathrm{a}$ & $105 \pm 15 \mathrm{a}$ \\
1990 & & & & & \\
None & 12 & $75 \pm 6 \mathrm{a}$ & $54 \pm 12 \mathrm{a}$ & $7 \pm 2 \mathrm{a}$ & $136 \pm 14 \mathrm{a}$ \\
Early & 6 & $60 \pm 14 \mathrm{ab}$ & $66 \pm 11 \mathrm{a}$ & $11 \pm 7 \mathrm{a}$ & $137 \pm 16 \mathrm{ab}$ \\
Mid & 6 & $28 \pm 9 \mathrm{c}$ & $60 \pm 11 \mathrm{a}$ & $7 \pm 4 \mathrm{a}$ & $95 \pm 9 \mathrm{bc}$ \\
Late & 6 & $50 \pm 14 \mathrm{bc}$ & $32 \pm 8 \mathrm{a}$ & $2 \pm 1 \mathrm{a}$ & $84 \pm 18 \mathrm{c}$ \\
\hline
\end{tabular}

${ }_{3}$ See text for exact dates of defoliation periods.

${ }^{2}$ Within column and year, means with the same letter are not significantly different (L.S.D.; P<0.05). 
Table 2. Biomass reductions in herbage classes $\left(\%\right.$ and $\left.\mathrm{g} \mathrm{m}^{-2}\right)$, calculated as the difference between control cages and treatment cages, after heavy grasshopper defoliation occurring early-, mid-, or late-season. Fort Bayard, N.M. 1989 and 1990.

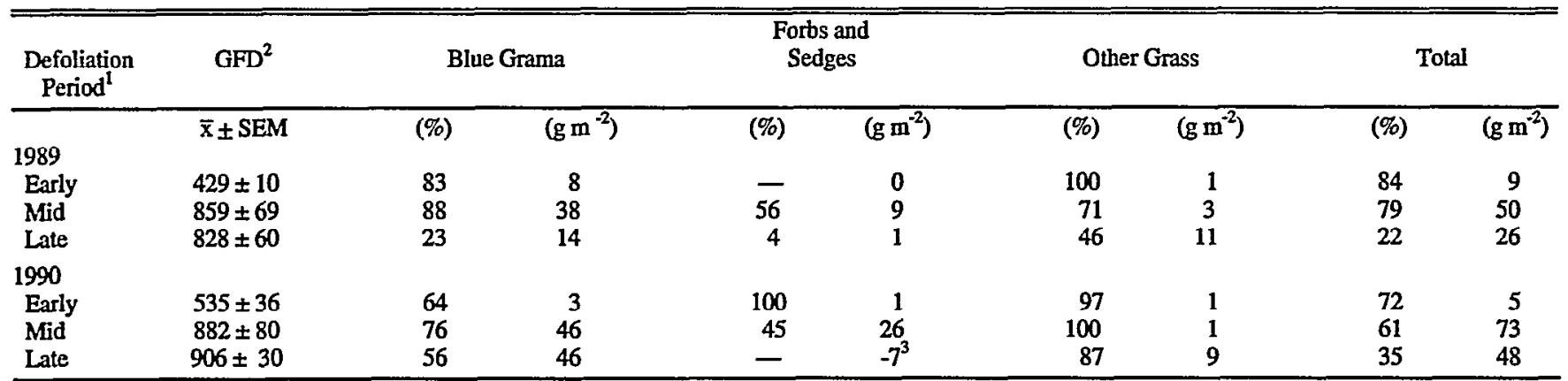

'Biomass estimates taken at the end of each defoliation period: Early—5 July 1989 and 29 June 1990; Mid—31 July 1989 and 8 August 1990; Late-31 August 1989 and 30 August 1990.

2Estimate of defoliation pressure, Grasshopper Feeding Days (GFD) $\pm \mathrm{SEM}$; $N=12$ cages per defoliation period.

${ }^{3}$ Value is negative because treatment cages were greater than control cages.

The importance of mid-season feeding damage was compounded by significant changes in the herbage composition. Forbs and sedges made up a larger percentage of the total herbage standing crop at PSC after mid-season defoliation during both years (Fig. 3 ), despite the fact that bigheaded grasshoppers destroyed more than $45 \%$ of the forb and sedge biomass after mid-season defoliation (Table 2). Olson et al. (1993) showed that intensive stocking of yearling steers had similar results on warm-season grasses: heavy blue grama defoliation during the active growth phase of both the grass and forbs resulted in increased densities of less desirable forbs.

Grasshopper pressure expressed as grasshopper feeding days (GFD) was lower during the early defoliation period in both years (Table 2). Very little green forage was available in the early defoliation period (Fig. 2), and, although grasshoppers removed an average of $78 \%$ of the available biomass, there was not enough forage to support the grasshopper population in each cage. The mortality rate increased rapidly after all available forage was removed, decreasing GFD during the early defoliation period. When adequate forage was available (mid- and late-season defoliation periods), grasshoppers destroyed from 36.9 to $81.7 \mathrm{mg}$ dry weight of total forage $\mathrm{GFD}^{-1}$. These data are similar to published bigheaded grasshopper forage destruction rates that ranged from
15.7 to $97.2 \mathrm{mg}$ per GFD (Hewitt et al. 1976, Thompson et al. 1995). At outbreak levels, bigheaded grasshoppers will remove grass to the crown level, grazing grass more severely than even the highest stocking rates of livestock (Pfadt and Hardy 1987a). Not surprisingly, in this study bigheaded grasshoppers stocked at densities of 80 grasshoppers $\mathrm{m}^{-2}$ destroyed most of the available forage (Table 2). In all of the early-season cages and in most of the mid-season cages grasshoppers removed all available green grass.

In years with above average winter and spring moisture, grass and forb growth increases. Most of the southwestern grasshopper species whose numbers increase dramatically during an outbreak use this early season resource (Nemey 1961). Grasshopper population densities near our research site peaked in April and May and decreased rapidly in June (Fig. 4) before the warm-season grasses began to grow (Fig. 2). The grasshopper species composition at our research site was similar to that reported by Nerney $(1960$, 1961) and Pfadt (1982) at the San Carlos Indian Reservation about $190 \mathrm{~km}$ west of Fort Bayard, N.M. Bigheaded grasshoppers, the primary gramnivore near our sites, made up $58 \%$ of the total grasshoppers collected during both years. Members of the genus Melanoplus and all other grasshoppers combined made up 29\% and $13 \%$ of the grasshoppers, respectively. Migratory grasshop-
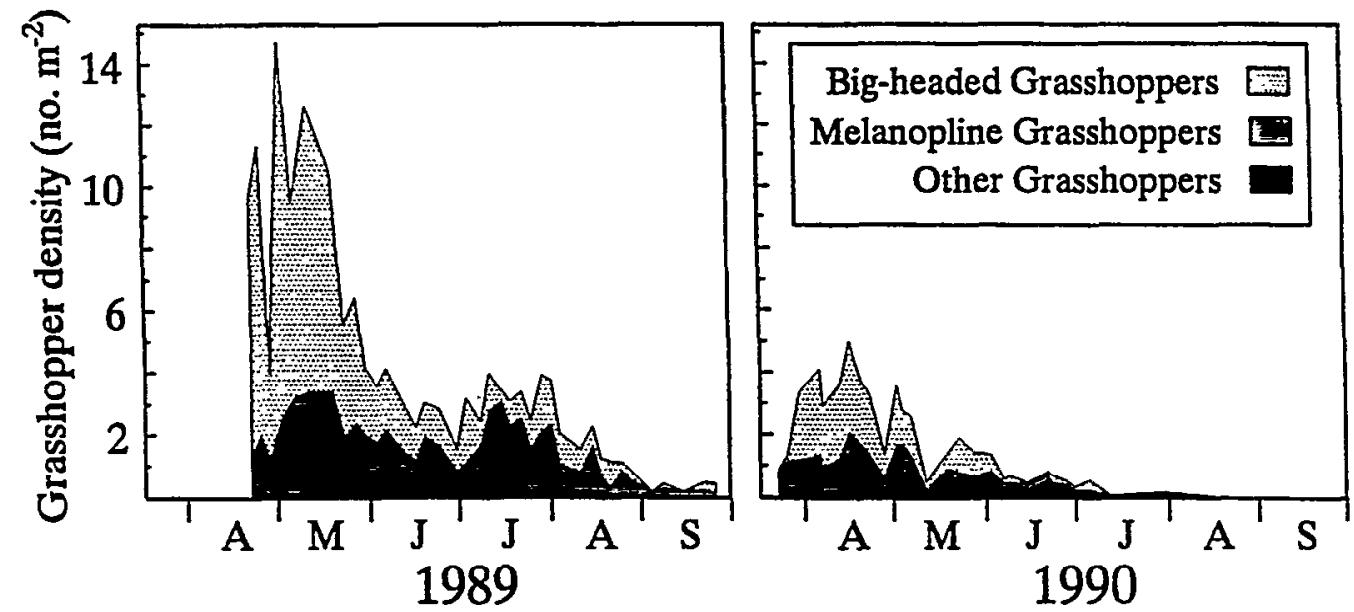

Fig. 4. Average density of grasshoppers (no. $\mathrm{m}^{-2}$ ) at a site near Fort Bayard, N.M., 1989 and 1990. Density estimates were taken biweekly using twenty $1.0 \mathrm{~m}^{2}$ night cages. The total density is divided into the 3 groups of grasshoppers listed. 
pers [Melanoplus sanguinipes (Fabricius)] and flabellate grasshoppers [Melanoplus occidentalis (Thomas) $=M$. cuneatus Scudder (Richman et al. 1993)] made up 72\% and 26\%, respectively, of all adult grasshoppers collected from this genus. Bigheaded grasshoppers, flabellate grasshoppers, and migratory grasshoppers all exhibited similar phenologies (Fig. 4). Each of these species is considered an early-season grasshopper that can be damaging to rangeland, although migratory and flabellate grasshoppers are not usually a problem on grasslands dominated by warm-season grasses (Pfadt et al. 1988). In both years, bigheaded grasshoppers were all adults by 15 June and migratory and flabellate grasshoppers were all adults by 1 July before the warm-season grasses began to grow (Fig, 4).

On rangelands where cool-season grasses dominate, damage by bigheaded and migratory grasshoppers may be severe and irreplaceable if not controlled early (Hewitt and Onsager 1983); thus, high early-season nymphal populations of these grasshoppers commonly serve as triggers for large-scale management programs (Pfadt and Hardy 1987b). On rangelands dominated by cool-season grasses economic benefits are greatest when third instar grasshoppers are targeted (Onsager 1984). Using nymphal populations as triggers for management programs may not be warranted on rangelands dominated by warm-season grasses that experience monsoonal late-summer precipitation. No management program should start until warm-season grasses are actively growing, contrary to grasshopper control guidelines used in the northern half of the western U.S. The substantial declines in grasshopper densities in June and July are common on southwestern rangelands (Pfadt 1982, Nemey 1960, 1961), as a result, high densities of early-season grasshoppers most often will not influence herbage production. If grasshopper densities remain high and control becomes necessary, carbaryl or malathion will provide $>90 \%$ control of adult grasshopper populations (Onsager 1978). Unless early-season forb production is an important part of a ranch management plan, the damage potential of early- and midseason grasshopper species may be lower on southwestern rangelands where mid- to late-summer precipitation patterns occur than reported in the literature for other areas of the western United States due to later maturation of warm-season grasses. Grasshoppers will compete with livestock for early season forage in years when grasshopper densities are high. However, in most years, depending upon precipitation patterns, there should be adequate growth following heavy early-season herbivory to feed both livestock and grasshoppers.

\section{Literature Cited}

Anderson, N.L. 1961. Seasonal losses in rangeland vegetation due to grasshoppers. J. Econ. Entomol. 54:369-378.

Ball, E.D., E.R. Tinkham, R. Flock, and C.T. Vorhies. 1942. The grasshoppers and other Orthoptera of Arizona. Ariz. Agr. Exp. Sta. Tech. Bull. 93:255-373.

Berry, J.S., W.P. Kemp, and J.A. Onsager. 1991. Integration of simulation models and an expert system for management of rangeland grasshoppers. Appl. Nat. Resour. Manage. 5:1-14.

Bonham, C.D. 1989. Measurements for terrestrial vegetation. John Wiley \& Sons, N.Y.

Capinera, J.L. and T.S. Sechrist. 1982. Grasshoppers (Acrididae) of Colorado: Identification, biology and management. Colo. Agr. Exp. Sta. Bull. 584S.

Detling, J.K., M.I. Dyer, and D.T. Winn. 1979. Net photosynthesis, root respiration, and regrowth of Bouteloua gracilis following simulated grazing. Oecologia 41:127-134.
Dyer, M.I. and U.G. Bokhari. 1976. Plant-animal interactions: studies of the effects of grasshopper grazing on blue grama grass. Ecology 57:762-772.

Hardman, J.M. and S. Smoliak. 1982. The relative impact of various grasshopper species on Stipa-Agropyron mixed prairie and fescue prairie in southern Alberta. J. Range Manage. 35:171-176.

Hewitt, G.B. 1977. Review of forage losses caused by rangeland grasshoppers. USDA-ARS Misc. Pub. No. 1348. 22p.

Hewitt, G.B. 1978. Reduction of western wheatgrass by the feeding of 2 rangeland grasshoppers, Aulocara elliotti and Melanoplus infantilis. J. Range Manage. 71:419-421.

Hewitt, G.B. and J.A. Onsager. 1983. Control of grasshoppers on rangeland in the United States -A Perspective. J. Range Manage. 36:202-207.

Holechek, J.L., R.D. Pieper, and C.H. Herbel. 1989. Range Management Principles and Practices. Prentice Hall, Englewood Cliffs, N.J.

Mitchell, J.E. 1975. Variation in food preference of 3 grasshopper species (Acrididae: Orthopetra) as a function of food availability. Amer. Midl. Nat. 94:267-283.

Nerney, N.J. 1960. Grasshopper damage on shortgrass rangeland of the San Carlos Apache Indian Reservation, Arizona. J. Econ. Entomol. 53:640-646.

Nerney, N.J. 1961. Effects of seasonal rainfall on range condition and grasshopper population, San Carlos Apache Indian Reservation, Arizona. J. Econ. Entomol. 54:382-385.

Olson, K.C., J.R. Brethour, and J.L. Launchbaugh. 1993. Shortgrass range vegetation and steer growth response to intensive-early stocking. J. Range Manage. 46:127-132.

Onsager, J.A. 1978. Efficacy of carbaryl applied to different life stages of rangeland grasshoppers. J. Econ. Entomol. 71:269-273.

Onsager, J.A. 1984. A method for estimating economic injury levels for control of rangeland grasshoppers with malathion and carbaryl. J. Range Manage. 37:200-203.

Pfadt, R.E. 1982. Density and diversity of grasshoppers (Orthoptera: Acrididae) in an outbreak on Arizona rangeland. Environ. Entomol. 11:690-694.

Pfadt, R.E. 1989. Bigheaded grasshopper, Aulocara elliotti (Thomas). Wyo. Agr. Exp. Sta. Bull. 912.

Pfadt, R.E. and D.M. Hardy. 1987a. A historical look at rangeland grasshoppers and the value of grasshopper control programs, p. 183-195. In: J.L. Capinera (ed.), Integrated pest management on rangeland: A shortgrass prairie perspective. Westview Press, Boulder, Colo.

Pfadt, R.E. and D.M. Hardy. 1987b. Conducting a rangeland grasshopper control program: A chronology. Wyo. Agr. Exp. Sta. B-882.

Pfadt, R.E., J.A. Lockwood, and T.M. Foppe. 1988. Diets of 3 common grasshoppers (Orthoptera: Acrididae) inhabiting desert grassland. Can. Entomol. 120:415-424.

Pieper, R.D. and C.H. Herbel. 1982. Herbage dynamics and primary productivity of a desert grassland ecosystem. N.M. Agr. Exp. Sta. Bull. 695.

Richman, D.B., D.C. Lightfoot, C.A. Sutherland, and D.J. Ferguson. 1993. A manual of the grasshoppers of New Mexico, Orthoptera Acrididae and Romaleidae. N.M. State Univ. Coop. Ext. Ser. Handb. \#7.

Quinn, M.A., P.S. Johnson, C.H. Butterfield, and D.D. Walgenbach 1993. Effect of grasshopper (Orthopetra: Acrididae) density and plant composition on growth and destruction of grasses. Environ. Entomol. 22:993-1002.

SAS Institute Inc. 1990. SAS procedures guide, version 6, third edition, Cary, N.C.:SAS Institute Inc.

Summers, C.G., RE. Garrett, and E.G. Zalom. 1984. New suction device for sampling arthropod populations. J. Econ. Entomol. 77:817-823.

Thompson, D.C. 1988. Distributional properties and optimal sampling of shortgrass rangeland grasshoppers. PhD. Diss.. Colo. State Univ.

Thompson, D.C., L.A. Torell, E.W. Huddleston, and J.H. Davis. 1995. Forage destruction by Aulocara elliotti (Orthoptera: Acrididae) on rangeland in the southwestern United States. J. Econ. Entomol. 88:1455-1460.

Torell, L.A., E.W. Huddleston, J.H. Davis, and J.M. Fowler. 1987. Losses from grasshoppers on New Mexico rangelands, 1954-1986, and the economic potential for control programs. N.M. Agr. Exp. Sta. Bull. 728.

White, M.R., R.D. Pieper, G.B. Donart, and L. White Trifaro. 1991. Vegetational response to short-duration and continuous grazing in south central New Mexico. J. Range Manage. 44:399-403. 